\title{
Teacher Perception on Educational Informatics Network: A Qualitative Study of a Turkish Anatolian High School
}

\author{
Halit Karalar ${ }^{1} \&$ Ugur Dogan ${ }^{2}$ \\ ${ }^{1}$ Department of Computer Education and Instructional Technologies, Faculty of Education, Muğla Sitkı Koçman \\ University, Muğla, Turkey \\ ${ }^{2}$ Department of Educational Sciences, Faculty of Education, Muğla Sttkı Koçman University, Muğla, Turkey \\ Correspondence: Halit Karalar, Department of Computer Education and Instructional Technologies, Faculty of \\ Education, Muğla Sitkı Koçman University, 48000, Muğla, Turkey. Tel: 90-252-211-5577. E-mail: \\ halit@mu.edu.tr
}

Received: October 14, 2016

Accepted: November 15, 2016

Online Published: March 30, 2017

doi:10.5539/ies.v10n4p101

URL: https://doi.org/10.5539/ies.v10n4p101

\begin{abstract}
FATIH Project carried out by the Turkish government is one of the comprehensive technology integration project in the World. With this project, interactive boards, tablets and multifunctional printers have been distributed to schools and Internet infrastructure of schools improved. EIN (Educational Informatics Network) platform, known as EBA (Eğitim Bilişim A $\breve{1})$ in Turkey, has been established to access the digital content to be used in conjunction with this technology. In this qualitative study, the process of using EBA was examined by benefiting from teachers' opinions and experiences; and it was aimed at revealing the problems experienced by teachers while using EBA and opinions regarding the alternatives for existing problems. Based on the content analysis of teachers' answers, it was concluded that problematic conditions as insufficient systematic structure and content of EBA, inappropriate content for students' needs and grade level, incompatibility with the changes in instructional programs, central exams pressure, and students' concentration on teacher-oriented approach had negative impacts on teachers unwilling and/or insufficient EBA use. Therefore, a model was presented to include teachers' recommendations which are composed of three strategies for the solution of the problems they experienced while using EBA.
\end{abstract}

Keywords: EBA, EIN, FATIH project, technology integration, Turkey

\section{Introduction}

Information and Communication Technologies (ICT) have become an indispensable part of education. Technology integration in education has been situated in the center of the national educational policies around the world for the purposes such as students being able to acquire the skills of 21 st century, be prepared for the future business world, and schools to become more effective and productive (Kirschner \& Erkens, 2006). Accordingly, several projects, known as "One-X-Per-Child", have been conducted for the technology integration in education in different countries (see Kim \& Jung, 2010; Pruet, Ang \& Farzin, 2015; Viriyapong \& Harfield, 2013).

The foundation of the technology integration in Turkish education has been laid by the "Project e-Transformation Turkey" and "Vision 2023 Certificate of Strategy." Independent studies being performed with the Project e-Transformation Turkey were gathered in the same body (State Planning Organization, SPO, 2006), and the emphasis on the Vision 2023 Certificate of Strategy prepared by the Scientific and Technological Research Council of Turkey (STRCT) is that

"having a learning and human-oriented educational system in which each individual can improve themselves at the maximum level in accordance with their qualities through considering and evaluating individual differences, which is freed of the limitations of time and space, has created idiosyncratic learning technologies and has the power to renew itself through the flexibility of change" (STRCT, 2004, p. 9).

In this context, projects including Dyned, ThinkQuest, Intel Teacher Program, Web-Based Content Development, and Cisco Network Academy have been carried out by the Ministry of National Education (MONE) to ensure that technology is efficiently used in education. One of the recent projects carried out by MONE for the 
technology integration in education has been the project of FATï (Fırsatları Arttırma ve Teknolojiyi İyileştirme Hareketi-Movement of Enhancing Opportunities and Improving Technology).

According to the official project document (FATIH Project, 2016), the objectives of the FATIH project were identified as forming structures suitable for students to improve themselves through the life-long learning approach and e-Learning and developing the e-Content, ensuring that each student graduating from a secondary-level school has the efficacy of using basic information and communication technologies, that one out of every three individuals benefits from e-education services through Internet, offering everyone learning and using the information and communication technologies, ensuring that every other individual becomes an Internet user, and making the Internet become a reliable medium for all sections of the society. In order to achieve the objectives of the project, completed 1st, 2nd, and 3rd phase, totally 582.288 interactive whiteboard, 2.189.400 tablet PCs and 41.996 multifunction printer were distributed to Turkish schools and 424.250 teachers have been given in-service trainings about FATIH Project in Education so far.

The FATIH project was divided into 5 main components, or subprojects, so that those objectives could be achieved. (1) Establishing the Hardware and Software Infrastructure, (2) Providing and Managing the Educational e-Content, (3) Efficient IT Use in Instructional Programs, (4) In-service Trainings for Teachers, (5) Ensuring the Conscious, Safe, Manageable and Measurable Use of ITs (Alkan, Bilici, Akdur, Temizhan, \& Barles, 2011).

It was planned with the main component of "Providing and Managing the Educational e-Content" the platform of EBA (Eğitim Bilişim Ağı-Educational Informatics Network) so that the e-Contents to be used with the technologies that will be integrated with the learning-teaching environments can be accessed. In this context, the EBA, which is a social education platform, was developed by the General Directorate of Innovation and Education Technologies to meet the needs of e-Content to be used along with the technologies integrated with learning-teaching environments (EBA, 2015). Main EBA applications are EBA Market, EBA Search, EBA Course, EBA Share, EBA Studios and Content Development Tools (FATIH Project, 2016). Digital contents are prepared as purchasing contents via grant from private sector firms that primarily develop e-Contents and companies developing content in this area in order to increase the number of content in the EBA platform (Alkan et al., 2011).

\subsection{Related Literature}

It is criticized that teachers and students are not sufficiently informed of the FATiH project. The study performed by Şahin, Aktürk, and Çelik (2013) supports this criticism, and it was concluded in the study that students and teachers do not have enough knowledge about the project. In the study performed by Ayvacı, Bakırc1, \& Başak (2014), it was observed regarding the implementation that there are problems about project's five main elements; they have problems especially about "Providing and Managing Educational e-Content" such as tablet PCs' limited content and how visuality is not in the forefront. In a similar research (Banoğlu, Madenoğlu, Uysal, \& Dede, 2014), it is stated that great part of teachers are facing the problems of low number of e-contents which are technically insufficient. In parallel with these studies, Bilici (2011) states that over half of the teachers do not benefit from the e-content in the class, majority of them cannot access to enough of e-content about their branches and over half of them report that these contents do not support the course attainments.

No matter how studies on using interactive boards in learning-teaching environments conclude that teachers need in-service training on this activity (Ayvac1 et al., 2014; Bilici, 2011; Türel, 2012), some show that teachers are in a positive attitude towards interactive boards (Somyürek, Atasoy, \& Özdemir, 2009; Pamuk, Çakır, Ergun, Y1lmaz, \& Ayas, 2013) and interactive boards are used by teachers to a large extent (Banoğlu et al., 2014; Kurt, Kuzu, Dursun, Güllüpınar, \& Gültekin, 2013; Türel, 2012). Yet, this is actually using the interactive boards as projectors (Kurt et al., 2013; Pamuk et al., 2013). It can be said that the main problem here stems from the lack of interactive content to be used together with interactive boards (Somyürek et al., 2009).

Tekerek, Altan, and Gündüz (2014) state that students have positive attitudes towards using tablet PCs, they enjoy using tablet PCs and they think that this technology will be effective on getting a good future career. On the other hand, Akcaoglu, Gumus, Bellibas, and Boyer $(2015$, p. 487) stress that "students couldn't use the tablets for 'creative' purposes due to the functionality limitations in the tablets". Similarly, Pamuk et al. (2013) stated that tablet PCs do not contribute to learning that much because students regard tablet PCs rather as an entertaining tool and the contents are lacking and insufficient. Accordingly, it was found in the same research that the level of using tablet PCs is very low. Teachers reported that they did not use tablet PCs because they decreased the eye contact, it was hard to manage the class since students' had interest in tablet PCs, the content for courses was not sufficient, their tablet PCs had the same applications with student tablet PCs and there was 
no Internet connection (Kurt et al., 2013). Similarly, Pamuk et al. (2013) concluded that teachers did not use tablet PCs for reasons such as lack of knowledge and skills of how to use the technological instruments provided within the scope of the project, lack of suitable course materials for the style of instruction and student characteristics, and incompatibility of instructional methods and strategies with the technologies of the project.

While interactive boards and tablet PCs share different problems that have an impact on their effective use in the teaching-learning process, it is seen that the common problem is the lack of digital content to be used along with those technologies (Ayvac1 et al., 2014; Bilici, 2011; Kurt et al., 2013; Pamuk et al., 2013; Somyürek et al., 2009). Researchers in the field of technology integration have put forward that teachers in particular and access to educational resources are vital factors in the integration of technology (Ertmer, 2005; Hew \& Brush, 2007; Mishra \& Koehler, 2006). Thus, it is highly important for the project to be able to succeed that EBA, which is responsible for providing content to be used with interactive boards and tablet PCs, is to be examined in a more detailed way and problems experienced by teachers while using EBA and recommendations for solutions are to be revealed. Yet, previous studies have remained limited to the use of interactive boards and tablet PCs within the context of the FATIH project in general. That is why more detailed qualitative research studies are needed to investigate the opinions of teachers who use the EBA platform. The study presents a need analysis for the EBA developers and sheds light on the development of proper strategies for extending and improves the use of EBA.

\subsection{Purpose of the Research}

In the study, the process of using EBA was examined by benefiting from teachers' opinions and experiences and it was aimed at revealing the problems experienced by teachers when using the EBA during this process and opinions regarding the solution to those problems. To this end, it is sought for answer to the following questions:

- How do teachers use the content in EBA in the class?

- What are the problems that teachers encounter with EBA?

- What recommendation do teachers provide about solutions to the problems with EBA?

\section{Method}

\subsection{Participants}

When selecting the participants of the research, the criterion sampling and the maximum variation sampling, which are purposive sampling methods, were used. The purposive sampling method is utilized for selecting individuals who are thought to have rich knowledge about a given situation so that it can be investigated in depth (Patton, 2014). The criteria used for selecting the research participants are whether the project was being carried out at a pilot school specified within the FATIH project, whether there was no problem with the Internet infrastructure that would hinder the use of EBA and a fiber Internet infrastructure, and whether teachers had received training for EBA use. An Anatolian High School was determined which met these criteria, and it was ensured that a teacher of each branch participated in the research reflecting maximum variation sampling (Yıldırım \& Şimşek, 2008). Our final participants consisted of 7 teachers of various subjects (biology, history, physics, chemistry, geography, literature and mathematics). 3 teachers were male and 4 females. In terms of experience in teaching, teachers ranged from having fourteen to twenty-two years.

\subsection{Data Collection Tolls}

By utilizing the literature and researchers' experiences, a semi-structured interview form composed of open-ended questions was developed to use in the interviews. The interview form was primarily examined by 3 experts and adjustments were made in accordance with their feedback. An expert of Turkish teaching was asked to examine if questions had any incoherency and were hard to understand and necessary adjustments were made. The interview form was used with two teachers apart from the study group in the pilot study; as a result, the questions were checked if they were apprehensible. It was also determined whether teachers were willing to talk about certain subjects, and questions were finalized. The interview form included a total of 7 questions that were formed on the three main research questions of the study.

The interview form is composed of the following questions: How do you use the content in EBA in your courses? Could you give an example of content you have recently used? What kind of contents do you use other than EBA? What are the problems you encounter while using EBA? Could you mention about the problems you experience, if any? What are the reasons behind these problems? What should be done to solve the problems with EBA? These questions were asked to all participants respectively, and some questions were also asked in the end according to the flow of the interview to get more information from the teachers. The interviews were recorded with a voice recorder and 206 minutes' voice record was obtained within the scope of the research with 
the shortest interview being 25 minutes and the longest one being 45 minutes. The voice records were decoded into the computer environment word by word and a document of 42 pages in total was obtained. The texts were presented to the participant teachers in hard copies, they were allowed to make changes in the texts, and the texts were finalized after the approval of the teachers.

\subsection{Procedure}

Before the study was conducted, the researchers visited the school for preparations as getting permission from administration board, greeting and informing the teachers, determining volunteers, and scheduling the interviews. In the following visit, interviews were conducted and what teachers explained were recorded digitally.

\subsection{Data Analysis}

The data obtained in the research were analyzed with the content analysis technique. NVivo 11, which is a computer-aided qualitative data analysis software, was used in the data analysis. In order to ensure the reliability of the data, the process of coding and designation of the themes was carried out by the researchers independently in the data analysis. As a result, it was seen that there was a $94 \%$ agreement in coding. In addition, the data were presented in details through direct citations as much as possible (Yıldırım \& Şimşek, 2008).

\section{Findings}

\subsection{How do Teachers Use EBA in the Class?}

Teachers' opinions on using EBA in the class and related themes are shown in Figure 1. All of the teachers assume the teacher-oriented approach in the class. Factors such as the structure of university entrance exams, parents' and students' expectations from teachers for achievement in those exams, the activities in the textbooks taking much time, short class hours, and the concern that the curriculum cannot be delivered in time are effective on the teachers adopting the teacher-oriented approach rather than the paradigm of constructivism in the instructional programs. In other words, even if teachers want to establish an instructional environment in accordance with the constructivist paradigm, these factors compel them to apply a teacher-oriented practice. On this compulsion, the History teacher remarked "When I review the questions asked in LGS and LYS exams [university entry exams], I see that there are questions directly about the subjects in the textbooks. Especially there are questions about the statements written in bold. You're making the students participate in the best activities, but they're asking about information based on memorization. I want to teach my students the importance of knowing the history, ensure that they develop different perspectives but the system of exams compels us to transfer the information in the books to the students. Because students and parents have different expectations from me." The Physics teacher added "The class hours are really short. There are good activities in the books but it's like a dream to be able to perform them completely. We're discussing it between friends, many of them aren't applying them, either. I know the student learn better when doing and experiencing something, but will we teach the subject or solve questions or make them perform activities within those limited class hours? This exam thing is really clipping our wings." On how the teachers are uncomfortable with the situation, the Literature teacher stated "We're taking the constructivism from the West. But they don't have any concerns about exams. Yet, our children are taking exams, but the exam asks questions not only from the textbook but also from extra subjects. Then we become bad teachers. There's something wrong with this."

The main approach adopted by the teachers during the teaching-learning process is to transfer the information necessary for students to succeed in university entry exams to them and to solve the questions about the subject in the test books. This approach or the style of practice affects the use of EBA during the teaching-learning process indirectly. It is understood from the explanations made by the teachers on how they use EBA in the class that they use the textbooks on EBA, they do not prefer the lecturing videos, and they use the pictures (statics-map, images, etc. and dynamics-animation, simulation, videos) and tests that enable the students to learn easily and reinforce the learning during the information transfer process so that they can attract their attention and summarize the subject. For example, the History teacher asserted "I downloaded the textbooks electronically and saved on the interactive board. Then, I teach the subject, have them watch video and I use the maps prepared for the history. I sometimes have them watch video in the beginning, then I teach the subject myself." whereas the Literature teacher remarked "For example, I teach the subject for a month, then have the students watch videos as the summary of the subject. We pass the lecturing parts of the videos because we've watched videos for lecturing before, and I take down notes which parts of the video I'll use in the class. Indeed, video sometimes gets so interesting in certain parts that it's like it explains to someone which doesn't know the subject." The Mathematics teacher remarked "It depends on the type of content and the need. We sometimes use it in the middle of the class hour, in the beginning or during the evaluation. I use animations and simulation about the subject, if any." The English teacher stated "I have them watch video so that they can reinforce these kind of 
contents after I've taught the subject and had them do exercises." whereas the Chemistry teacher asserted "I prefer abstract contents. The atom subject, for example. One has to imagine for that subject, and I have to make lots of sentences so that the student can imagine or visualize it. Rather, it serves me much when I use a video or simulation on EBA." The Physics teacher stated "I've only used the test to date."

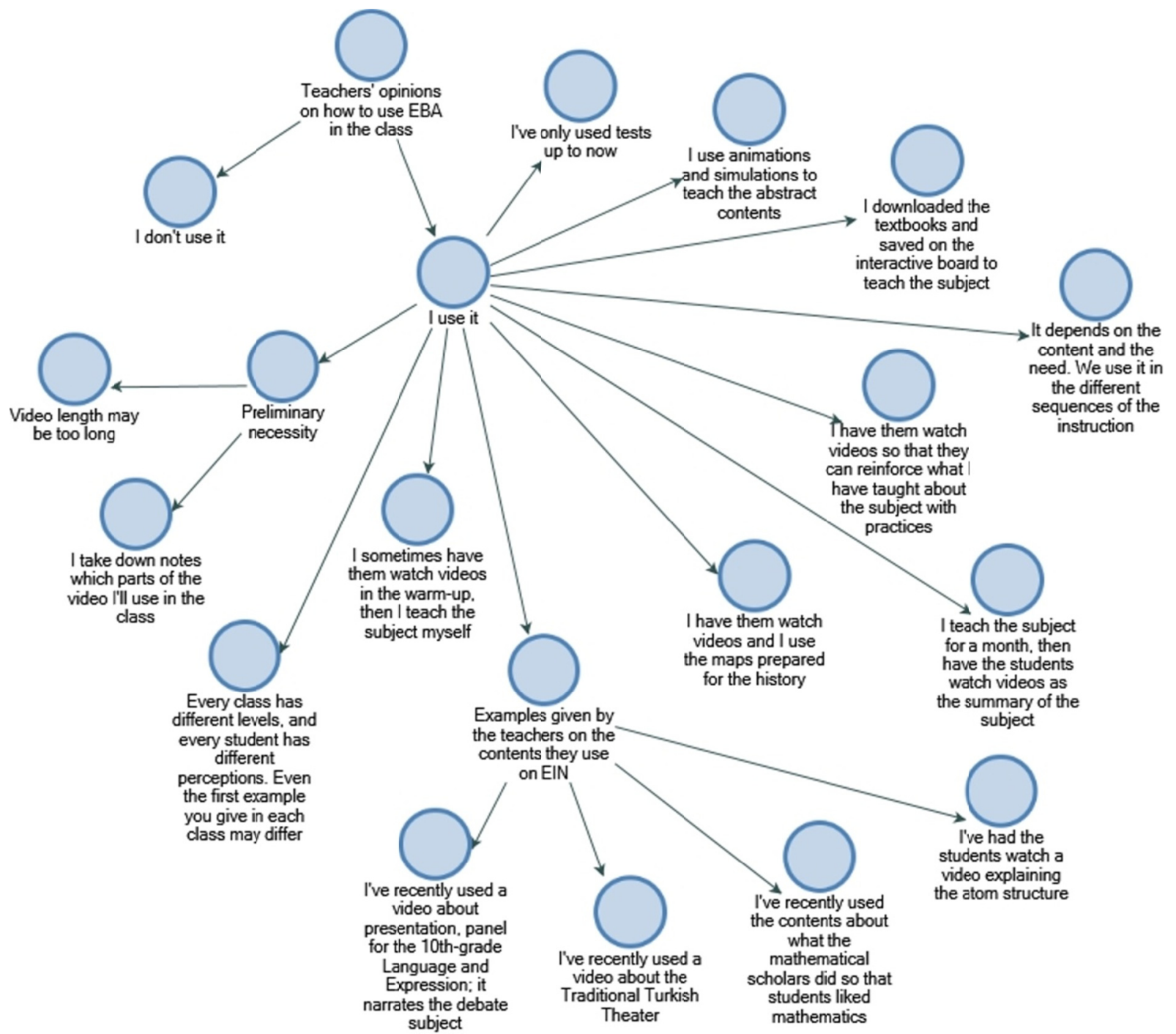

Figure 1. Teachers' opinions on how to use EBA in the class

It is noted that the examples given by the teachers on the contents they use on EBA in the class are limited. On the examples about the contents they use on EBA, the Chemistry teacher remarked "As far as I remember, I've had the students watch a video explaining the atom structure on EBA." The Literature teacher stated "There is a video about presentation, panel for the $10^{\text {th }}$ grade Language and Expression; I didn't like that. It narrates the debate subject. It begins with "what is debate?", two men come and begin fighting. Seriously, I mean it! A lady comes along and says "this is not a debate." Again, I'm telling you since I liked it, there is a video about the Traditional Turkish Theater." And the Mathematics teacher said "I've recently used the contents about what the mathematical scholars did so that students like mathematics. These contents are 2-3 minute videos that introduce those scholars". These examples show that teachers do not use EBA at a sufficient level.

So, what kind of contents do teachers use and where do they draw these contents other than EBA? The contents used by the teachers in the class are gathered under the themes of textbooks, Power Point presentations, the Internet and the contents of publishing houses. The Chemistry teacher stated "I rather use the textbook. And I use the question books." while the Literature teacher remarked "I use the textbook." and the History teacher said "I 
don't prepare [Power Point] presentations since the textbook changes almost every year. I just follow the textbook."

It is understood that the teachers use the Internet to access contents in the form of animation and simulation and download course presentations. On how they use the Internet for instructional purposes, the Biology teacher stated "I mostly benefit from foreign websites. For example, http://www.sumanasinc.com/, I often use the animations there in the class. And I find animations and simulations on different websites to use them in the class." The English teacher remarked "I rather benefit from foreign websites. http://wordsmith.org/ and Meg Classics Comic (www.gocomics.com/meg-classics) I use." whereas the Physics teacher said "I use the simulations of the Colorado University (https://phet.colorado.edu) in the class." and the Literature teacher asserted "I utilize normal websites rather than EBA. For example, I use www.edebiyatogretmeni.org and http://www.turkcedersi.gen.tr/." The Chemistry teacher added "I search with the Google search engine and review the results." The Mathematics teacher remarked "My primary source is the virtual platform. There are materials prepared on the virtual platform. For example, when you search for 'algorithm', many sources come up on the Internet. And there is this group, Band of Mathematics Teachers in Turkey; I follow their website." And the History teacher finally added "I rather use YouTube."

On the presentations used by the teachers in the class, the Chemistry teacher remarked "There are fellow teachers who are very talented at using computer and technology. They share the presentations they prepare in Facebook groups and via e-mail groups. I use presentations but I don't prepare them. I'm a free-rider and get the presentations prepared by a friend. But I make changes on the presentations on my own." The Literature teacher added "I find the presentations via the Internet and make adjustments on them." whereas the Mathematics teacher said "We revise the presentations we downloaded via the Internet in terms of attainment; you should relay the attainments of the course. For example, the basic attainments are available in an old resource, some are unchanged but there are several unnecessary attainments which we omit later. When specifying these omissions, we consider the need of the school and students. There is type of question which a student can understand and there is very hard or easy question. It is important to adjust it on the basis of students' levels." The Physics teacher finally added "I have had a system for years: I have presentations and I teach the class using them."

On the contents of publishing house, the Biology teacher remarked "I study the books of at least four different publishing houses and abstract the information in to present to my students. There is a CD [Compact Disc] that comes with the book and teaches the subjects. That CD is much more orderly than EBA, but I don't use it. I don't like adhere to one book only." The Chemistry teacher said "When I'm using the question book of a publishing house for a subject, I can use the book of another publishing house for another subject. It is very important for the students to exercise, so I recommend them to buy the books of different publishing houses." The Physics teacher remarked "I have contents from other publishing houses. The students change the force on it, can click on it to see how the momentum changes." The Literature teacher added "We have the students buy auxiliary books for the evaluative activities. When they buy them, they copy the contents compatible with the interactive board to our flash memories [USB memory] and they don't give them to the students. We use them directly through there. There is lecturing in those contents, accompanied by apprehending tests successively. But EBA doesn't have it." The Chemistry teacher finally said "I don't use the contents of a publishing house for lecturing and question solving. I use them only if they have videos or images."

\subsection{What are the Problems that Teachers Encounter with EBA During the Teaching-Learning Process?}

As seen in Figure 2, the problems that the teachers encounter with EBA stem from the lack of a systematic structure in EBA and problems with the content. Concerning the lack of a systematic structure in EBA, the Chemistry teacher stated "I can't find the content about classroom, course, units and subject, it's because EBA has a disorderly structure. If I'm looking for a video, I can't find it right away. The uploaded videos are presented in an uncategorized way; therefore, I have to turn them upside down." whereas the History teacher said "EBA is neither neat nor in order. EBA is like a large bag into which everything has been thrown. It's not orderly. There are many contents, many collections. They've thrown whatever they've found in." The English teacher remarked "The system looks like a warehouse; it's like everything is stored there." while the Literature teacher said "EBA works like YouTube. We enter the subject into the search area, but lots of videos are found in the search. We find it difficult to find what we look for."

The fact that platform structure of EBA is not a systematical one has a negative impact on the searching process and causes loss of time. On this problem, the Mathematics teacher remarked "It's messy. When we log in, all the courses are displayed together. It causes us to lose time to filter them." whereas the Biology teacher stated 
"When I want to log in the EBA, I want to find the $10^{\text {th }}$ grade subjects but I have to scan all the subjects to find what I look for. In the meantime, the students lose interest and I lose time in the end." The Biology teacher asserted "I'm very cautious about supporting the subjects with simulation and animation. But you can't find them immediately. You lose time." The Chemistry teacher explains "Since the students lose attention during the time I spend to find the videos, I don't prefer the EBA."

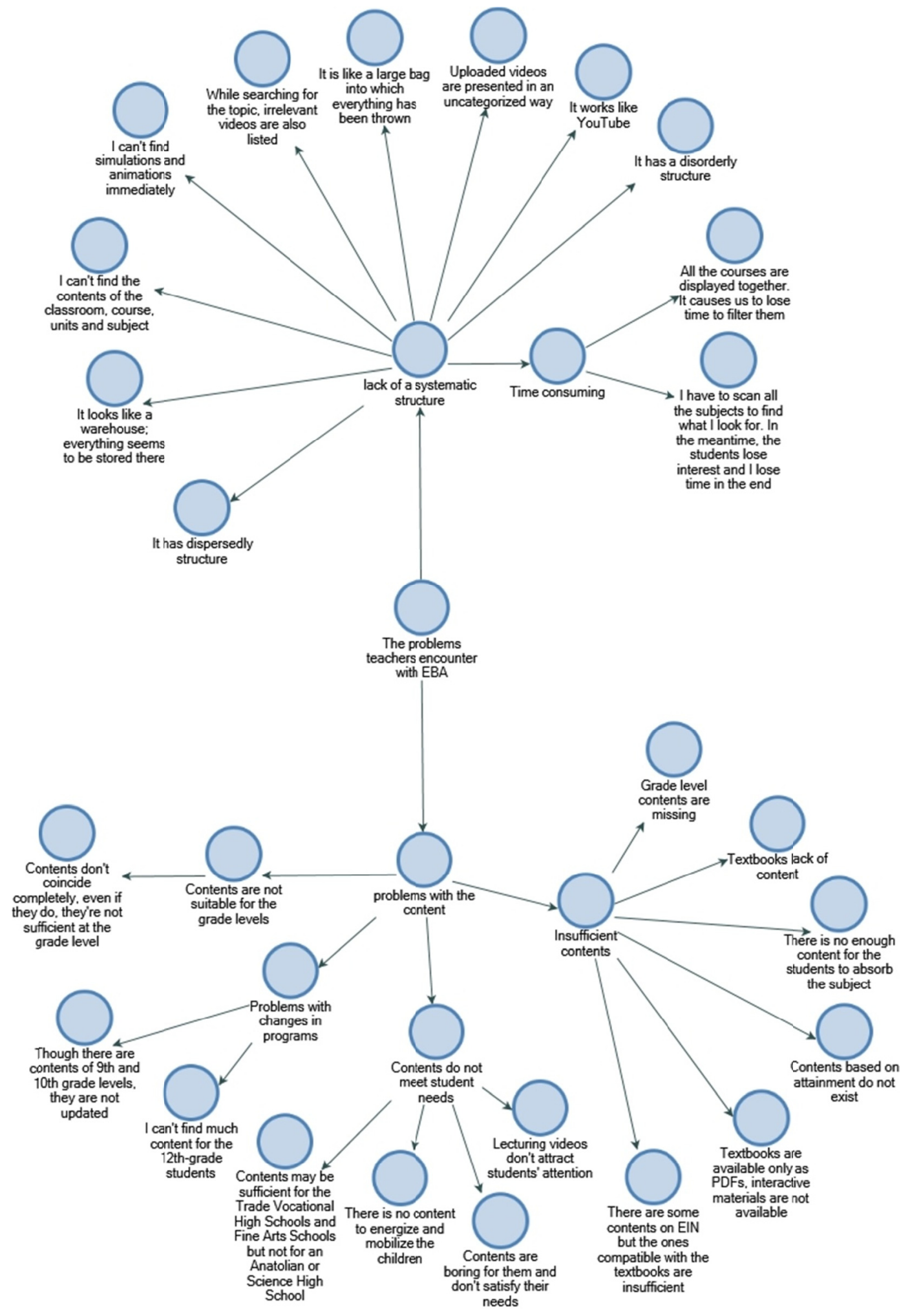

Figure 2. The problems teachers encounter with EBA 
The problems with the contents experienced by the teachers are gathered under the themes of "they do not meet student needs", "insufficient contents", "problems with changes in programs" and "they are not suitable for the grade level." Concerning the lack of content, the English teacher asserted "We have the interactive board but the contents of books sent to the schools are in the PDF format. Those books are lacking in the content. And we can't find the subjects to be taught on EBA." The History teacher mentioned "There are some contents on EBA but the ones compatible with the textbooks are insufficient. We have an elective course, the Culture History in the $11^{\text {th }}$ grade, the Modern Turkish History in $12^{\text {th }}$ grade but they don't have adequate contents." and the Literature teacher remarked "There are content problems with the $10^{\text {th }}$ grade Divan Literature. There are no contents in terms of attainment; we can find the subject titles for the units, but these aren't enough." Similarly, the Biology teacher stated "You're teaching the mitotic division in the $10^{\text {th }}$ grade, but you can't find which critical points to emphasis. There is no content enough for the students to absorb that subject, let alone for preparing for university exams or the school exams." and the Physics teacher asserted "It would be better if there were videos, animations and simulations that wouldn't take our time in comparison to the attainments. If there were contents that wouldn't stall us much and for which the students could say 'I've learned it once', it would be much better, but we can't find such contents. A lot of attainments can be in vain because they aren't visual."

The fact that the teacher cannot find the contents can be resulted from the changes in the instructional programs. The Chemistry teacher added "This year, this program is being applied for the last time in the $12^{\text {th }}$ grade, therefore I can't find much content for the $12^{\text {th }}$ grade students. It needs to be renewed the next year. Maybe it's because it's the transition for the system. Even though the programs of the 9th and 10th grades, there are still old-system publications on EBA." and the Literature teacher similarly added "The textbook are changing every year. Almost all books are changed every year and I can't find compatible contents. They've combined the Language and Expression and the Turkish Literature courses under the name of Turkish Language and Literature for the next year. They've made two courses into one. All subjects, positions and attainments of the subjects have been changed. It's definite that I won't be able to find any content for that course on EBA."

Concerning that the contents are not suitable for the target level, the Biology teacher remarked "The contents may be sufficient for the Trade Vocational High Schools and Fine Arts Schools but not for an Anatolian or Science High School. The contents don't coincide completely, even if they do, they're not sufficient at the grade level." and the Literature teacher stated "Lecturing videos don't attract students' attention; the contents are boring for them and don't satisfy their needs." as similarly the Biology teacher remarked "There is no content to energize and mobilize the children."

\subsection{What Kind of Recommendations do Teachers Provide for EBA?}

Teachers' recommendations for EBA are gathered under three themes: structural, educational system and strategies related to contents. Their recommendations concerning those strategies are presented in Figure 3 .

On the recommendations for the strategies related to contents, the History teacher remarked "There should be contents consistent with the textbook and to which we can easily access. The contents should be completely compatible with the textbook like what private companies do and ensure that students can take part in the class actively, and includes videos, exercises, question types, history maps, etc. along with the compatibility with tablet PCs. Shortcomings of course materials should especially be eliminated as soon as possible and constantly updated. Videos should be limited to 10 minutes." and the Physics teacher stated "If there were images and simulations, I would use them. Not large-size ones, they should be short and effective. Since our class hours are limited, I sometimes may not open long videos. It would be better if there were simulation-type contents that explain the core shortly and on which students could make changes." The Chemistry teacher added "There should be emphasis on contents and experiment videos in the format of video, animation and simulation which will support the lecturing and facilitate to understand the subject. The contents should be accessed at the level of class, course, unit, subject, and attainment. The contents can be divided into groups of Science high school, Anatolian high school and vocational high school separately or it may be specified for which high school the content is suitable." The Literature teacher asserted "There are no contents on EBA with which students can practice and we can make evaluations. Such contents should be added. The contents should allow us to use the interactive feature of the interactive board. The contents should be suitable for students' levels. Videos should be limited to 10 minutes so that we can use the class hour efficiently." The Mathematics teacher added "There should be contents created professionally on the basis of attainment. It is highly important that foreign resources are translated into Turkish and opened up for access through EBA." The English teacher stated "The ministry won't prepare the interactive CDs of the book. This should be the first task. For example, we've used an Oxford book; when you click on a picture of a current subject, it takes you there and you can access images related to the subject. And there should be different and rich contents that we can choose by attainment." 


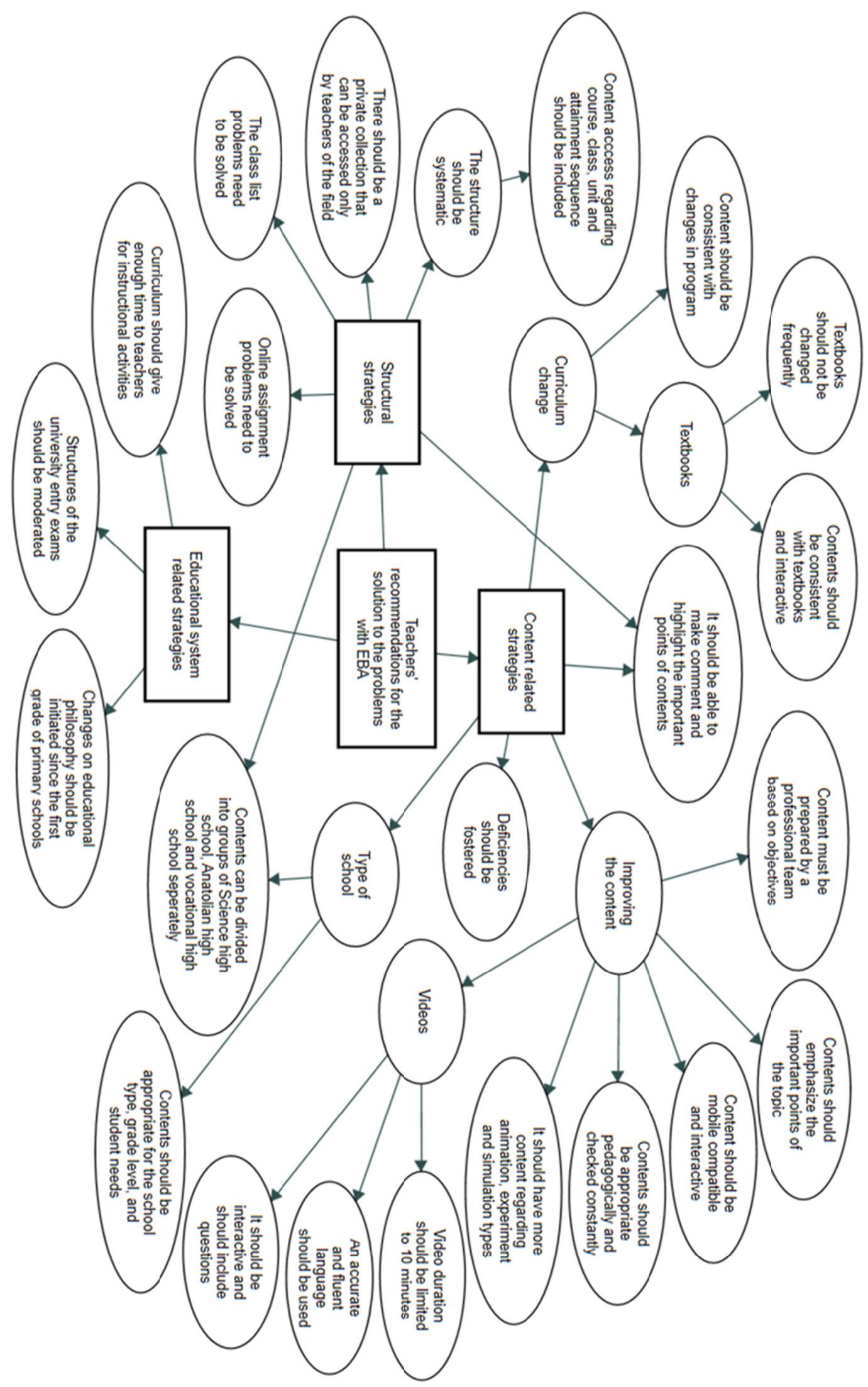

Figure 3. Model with the teachers' recommendations 


\section{Discussion and Conclusion}

The EBA platform was created to meet the need for the contents for the technologies with which classrooms had been equipped within the scope of the FATIH Project can be used more efficiently during the teaching-learning process. In this context, EBA is one of the most important components for the FATIH project to be successful. In this qualitative study, the process of using EBA was comprehended in an effort by benefiting from teachers' opinions and experiences and it was aimed at revealing the problems experienced by teachers when using the EBA during this process and opinions regarding the solution to those problems.

The results of our interviews revealed that use of EBA is negatively affected by the central exams, particularly for university entrance; academic achievement expectations of parents and students; and time consuming activities in course books and short class hours resulting from comprehensive curricula. As the university entry exams, high-stakes testing can be major barrier to the technology integration (Hew \& Brush, 2007). Akcaoglu et al. (2015) stress that students will mainly focus on contents and tactics for the vital exams instead of 21st century skills and activities as long as central exams exist.

It is known that practices and beliefs of constructivist paradigm are important predictors of the technology use (Ertmer \& Ottenbreit-Leftwich, 2010; Overbay, Patterson, Vasu, \& Grable, 2010). Even if teachers want to establish an instructional environment in accordance with the constructivist paradigm, these factors compel them to apply lecture-based teaching. In fact, it is not only the teachers in Turkey facing the situation, but it is similar for teachers in Taiwan (Liu, 2011), Slovenia (Fekonja-Peklaj \& Marjanovič-Umek, 2015), and Korea (Won, 2014). Cuban (1986) stresses that providing access to new technologies does not simply mean that teachers will enhance students' learning; rather, they will possibly be used to transfer knowledge. In this teaching approach, the teachers transfer the necessary information for students to succeed in university entry exams and mainly concern the questions about the subject in the test books. However, constructivist the curricula is prepared by the central government authorities, teachers will be solely a direct transformer of the technology and will be prevented from a constructive experience benefiting from technology use as long as the curricula in action aligns with preparing students to be successful in the exams. It will also derive teachers from achieve the FATIH project objectives for technology integration in education in nation-wide.

Lecture-based teaching affects the use of EBA during the teaching-learning process indirectly. Within this context, it is understood from the explanations made by the teachers on how they use EBA in the class that they use the textbooks on EBA by projecting them onto the interactive board, they do not prefer the lecturing videos, and they use the pictures (statics-map, images, etc. and dynamics-animation, simulation, videos of experiments) and tests that enable the students to learn easily and reinforce the learning during the information transfer process so that they can attract their attention and summarize the subject. This finding shows parallelism with the findings of numerous studies (Akcaoglu et al., 2015; Fekonja-Peklaj \& Marjanovič-Umek, 2015; Liu, 2011). It was also found that the teachers supplement the contents they could not find on EBA with textbooks, the Power Point presentations they prepare or download via the Internet, the Internet itself and the contents of publishing houses. It is understood that the teachers use the Internet to access contents in the form of animation and simulation and download course presentations and other contents.

It was found that the teachers have problems with the lack of a systematical structure in EBA and the contents during the teaching-learning process. The fact that structure of EBA is not a systematical one has a negative impact on the searching process and causes loss of time. It may cause barriers for technology to be integrated. It may also result in unfruitful instructional hours and students' losing interest for the topic. Content related problems can be stated as the lack of suitable content for students' needs and grade levels, attainments, and incompatibility with the program and continuous change of textbooks. Several studies (Ayvac1 et al., 2014; Banoğlu et al., 2014; Bilici, 2011; Pamuk et al., 2013) on the content problems in EBA support our findings of in the research. Indeed, insufficient content leading an important barrier for technology integration (Ertmer, 2005) has been one of the crucial barriers in ICT projects maintained by the MONE for a long time (Somyurek et al., 2009).

Ertmer (1999) explains the problems encountered during the integration of technology with education as internal and external obstacles. It can be said in this context that these problems are the external obstacles that hinder teachers' use of EBA and can be fixed in accordance with the recommendations in Figure 3 independently from teachers. The internal obstacles are about attitudes and beliefs of teachers concerning towards technology. As stated by the Chemistry teacher, teachers should be shown how to use EBA specifically for the branches in the class to enhance teachers' pedagogical value beliefs concerning the EBA. Within this context, it is highly important that the in-service training for EBA are based on each branch and EBA is supported with exemplary 
practices about how to use it to achieve certain instructional objectives and the project's desired outcomes.

The result of the study should be interpreted with some limitations. Number of participants in the research, ranging teachers' work of experience, and teachers' working school are the limitations of the research. Although the results cannot be generalized to Turkey as a whole, the research provides rich and detailed data. Yet, more qualitative research studies need to be conducted at different types of schools, with different teachers, especially with different experience so that several aspects of using EBA can be understood in depth.

\section{Acknowledgments}

A part of this study is presented as oral presentation at the 10th International Computer \& Instructional Technologies Symposium. This paper has been granted by the Mugla Sitk1 Kocman University Reasearch Projects Coordination Office, Project Grant Number: 15/215 and title: Teachers' Opinion Regarding Education Information Network.

\section{References}

Akcaoglu, M., Gumus, S., Bellibas, M. S., \& Boyer, D. M. (2015). Policy, practice, and reality: exploring a nation-wide technology implementation in Turkish schools. Technology, Pedagogy and Education, 24(4), 477-491. http://dx.doi.org/10.1080/1475939X.2014.899264

Alkan, T., Bilici, A., Akdur, T. E., Temizhan, O., \& Barles, A. (2011). Fırsatları arttırma teknolojiyi iyileştirme hareketi (FATIH) projesi. In Proceeding of 11th International Educational Technology Conference Book (Volume II) (pp. 1533-1538). Retrieved from http://www.iet-c.net/publication_folder/ietc/ietc2011-2.pdf

Ayvacı, H. Ş., Bakırc1, H., \& Başak, M. H. (2014). The evaluation of problems emerging during the işmplementation process of FATIH project by administrator, teachers and student. YYU Journal Of Education Faculty, 11(1), 20-46.

Banoğlu, K., Madenoğlu, C., Uysal, Ş., \& Dede, A. (2014). An investigation of teachers' perceptions of the implementation of the FATIH project (Eskisehir province case). Journal of Educational Science Research, 4(1), 39-58. http://dx.doi.org/10.12973/jesr.2014.4os3a

Bilici, A. (2011). Öğretmenlerin bilişim teknolojileri cihazlarının eğitsel bağlamda kullanımına ve eğitimde FATİH projesine yönelik görüşleri: Sincan İl Genel Meclisi İ.Ö.O örneği. In Z. Genç (Ed.), Proceeding of 5th International Computer and Instructional Technologies Symposium (pp. 784-790). Elazığ: Firat Üniversitesi.

EBA. (2015). Educational Informatics Network. Retrieved from http://www.eba.gov.tr/

Ertmer, P. A. (1999). Addressing first- and second-order barriers to change: Strategies for technology integration. Educational Technology Research and Development, 47(4), 47-61. http://dx.doi.org/10.1007/BF02299597

Ertmer, P. A. (2005). Teacher pedagogical beliefs: The final frontier in our quest for technology integration? Educational Technology Research and Development, 53(4), 25-39. http://dx.doi.org/10.1007/BF02504683

Ertmer, P. A., \& Ottenbreit-Leftwich, A. T. (2010). Teacher technology change: How knowledge, confidence, beliefs, and culture intersect. Journal of Research on Technology in Education, 42(3), 255-284. http://dx.doi.org/10.1080/15391523.2010.10782551

FATIH Project (2016). FATIH Project. Retrieved from http://fatihprojesi.meb.gov.tr/

Fekonja-Peklaj, U., \& Marjanovič-Umek, L. (2015). Positive and negative aspects of the IWB and tablet computers in the first grade of primary school: a multiple-perspective approach. Early Child Development and Care, 185(6), 996-1015. http://doi.org/10.1080/03004430.2014.974592

Hew, K. F., \& Brush, T. (2007). Integrating technology into K-12 teaching and learning: Current knowledge gaps and recommendations for future research. Educational Technology Research and Development, 55(3), 223-252. http://doi.org/10.1007/s11423-006-9022-5

Kim, J. H.-Y., \& Jung, H.-Y. (2010). South Korean digital textbook project. Computers in the Schools, 27(3-4), 247-265. http://dx.doi.org/10.1080/07380569.2010.523887

Kirschner, P., \& Erkens, G. (2006). Cognitive tools and mindtools for collaborative learning. Journal of Educational Computing Research, 35(2), 199-209. http://dx.doi.org/10.2190/R783-230M-0052-G843

Kurt, A. A., Kuzu, A., Dursun, Ö. Ö., Güllüpınar, F., \& Gültekin, M. (2013). Evaluation of the pilot application process of FATIH project: Teachers' views. Journal of Instructional Technologies \& Teacher Education JITTE, 1(2), 1-23. 
Liu, S.-H. (2011). Factors related to pedagogical beliefs of teachers and technology integration. Computers \& Education, 56, 1012-1022. http://dx.doi.org/10.1016/j.compedu.2010.12.001

Mishra, P., \& Koehler, M. J. (2006). Technological Pedagogical Content Knowledge: A Framework for Teacher Knowledge. Teachers College Record, 108(6), 1017-1054. http://doi.org/10.1111/j.1467-9620.2006.00684.x

Overbay, A., Patterson, A. S., Vasu, E. S., \& Grable, L. L. (2010). Constructivism and technology use: findings from the IMPACTing leadership project. Educational Media International, 47(2), 103-120. http://dx.doi.org/10.1080/09523987.2010.492675

Pamuk, S., Çakır, R., Ergun, M., Yılmaz, H. B., \& Ayas, C. (2013). The use of Tablet PC and Interactive Board from the perspectives of teachers and students: Evaluation of the FATIH project. Educational Sciences: Theory \& Practice, 13(3), 1799-1822. http://dx.doi.org/10.12738/estp.2013.3.1734

Patton, M. Q. (2014). Nitel araştırma ve değerlendirme yöntemleri (M. Bütün \& S. B. Demir, trans.). Ankara: Pegem Akademi.

Pruet, P., Ang, C. S., \& Farzin, D. (2015). Understanding tablet computer usage among primary school students in underdeveloped areas: Students' technology experience, learning styles and attitudes. Computers in Human Behavior, 55, 1131-1144. http://doi.org/10.1016/j.chb.2014.09.063

Şahin, Ş., Aktürk, A. O., \& Çelik, İ. (2013). A Study on teachers', students' and their parents' view on the FATIH project. International Journal of Social, Management, Economics and Business Engineering, 7(12), 1889-1895.

Somyürek, S., Atasoy, B., \& Özdemir, S. (2009). Board's IQ: What makes a board smart? Computers and Education, 53(2), 368-374. http://dx.doi.org/10.1016/j.compedu.2009.02.012

SPO. (2006). Bilgi Toplumu Stratejisi (2006-2010). Retrieved from http://www.resmigazete.gov.tr/eskiler/ 2006/07/20060728-7.htm

STRCT. (2004). Ulusal Bilim ve Teknoloji Politikalarl 2003-2023 Strateji Belgesi. Retrieved from http://www.tubitak.gov.tr/tubitak_content_files/vizyon2023/Vizyon2023_Strateji_Belgesi.pdf

Tekerek, M., Altan, T., \& Gündüz, I. (2014). Student's attitudes towards use of tablet PC's in FATİH project. International Journal of Informatics Technology (IJIT), 7(2), 21-27. doi:10.12973/bid.2017

Türel, Y. K. (2012). Teachers' negative attitudes towards interactive whiteboard use: Needs and problems. Elementary Education Online, 11(2), 423-439.

Viriyapong, R., \& Harfield, A. (2013). Facing the challenges of the One-Tablet-Per-Child policy in Thai primary school education. International Journal of Advanced Computer Sciences and Applications, 4(9), 176-184. http://dx.doi.org/10.14569/ijacsa.2013.040928

Won, S. S. (2015). Teachers' use of technology and its influencing factors in Korean elementary schools. Technology, Pedagogy and Education, 24(4), 1-16. http://doi.org/10.1080/1475939X.2014.915229

Yıldırım, A., \& Şimşek, H. (2008). Sosyal bilimlerde nitel araştırma yöntemleri (6nd ed.). Ankara: Seçkin Yayıncilik.

\section{Copyrights}

Copyright for this article is retained by the author(s), with first publication rights granted to the journal.

This is an open-access article distributed under the terms and conditions of the Creative Commons Attribution license (http://creativecommons.org/licenses/by/4.0/). 